\title{
Treatment of dermatophilosis with oxytetracycline and tylosin combination in Saanen goat kids
}

\author{
Uğur AYDOĞDU ${ }^{1, a, ®}$, Ersoy BAYDAR ${ }^{1, b}$, Mustafa USTA $^{2, c,}$ Banu DOKUZEYLÜL ${ }^{3, d}$, \\ Musa KARAMAN ${ }^{2, e}$, Ziya İLHAN ${ }^{4, f}$
}

\begin{abstract}
${ }^{1}$ Balıkesir University, Faculty of Veterinary Medicine, Department of Internal Medicine, Balıkesir; ${ }^{2}$ Balıkesir University, Faculty of Veterinary Medicine, Department of Pathology, Balıkesir; ${ }^{3}$ İstanbul University-Cerrahpaşa, Faculty of Veterinary Medicine, Department of Internal Medicine, İstanbul; ${ }^{4}$ Balıkesir University, Faculty of Veterinary Medicine, Department of Microbiology, Balıkesir, Turkey.

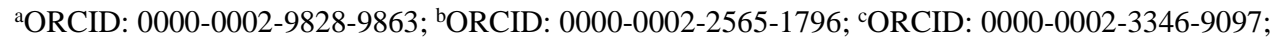

dORCID: 0000-0003-3086-4726; ${ }^{\mathrm{e} O R C I D: ~ 0000-0001-6721-6111 ; ~ f ~ O R C I D: ~ 0000-0003-3638-9196 ~}$
\end{abstract}

Corresponding author: ugur.aydogdu@balikesir.edu.tr

Received date: 26.08.2019 - Accepted date: 23.06.2020

\begin{abstract}
In this study, it was aimed to determine the treatment efficacy of oxytetracycline and tylosin combination in Saanen goat kids with Dermatophilus congolensis infection. Samples, were collected from the 27 of 4-5-month-old Saanen goat kids, and analyzed from bacteriological, mycological and ectoparasitological aspects. D. congolensis was isolated from the samples as pure culture. In the mycological analysis of the samples, no microorganisms were found, while flea was detected in ectoparasitological examinations. A combination of oxytetracycline and tylosin was recommended for dermatophilosis treatment, and the lesions regressed 5 days after the treatment and disappeared over time. It was concluded that $D$. congolensis infection in Saanen goats kids were observed for the first time in Turkey and can be treated successfully with oxytetracycline and tylosin combination.
\end{abstract}

Keywords: Dermatophilus congolensis, goat kid, oxytetracycline, tylosin

\section{Saanen oğlaklarında oksitetrasiklin ve tilosin kombinasyonu ile dermatofilozisin tedavisi}

Özet: Bu çalışmada, Dermatophilus congolensis enfeksiyonlu Saanen oğlaklarında oksitetrasiklin ve tilosin kombinasyonunun tedavi etkinliğinin belirlenmesi amaçlandı. Saanen 1rk1 4-5 aylık 27 oğlaktan toplanan örnekler bakteriyolojik, mikolojik ve parazitolojik açıdan analiz edildi. D. congolensis saf kültür olarak numunelerden izole edildi. Numunelerin mikolojik analizinde herhangi bir etkene rastlanmazken, ektoparazitolojik incelemeler sonucunda pire tespit edildi. Dermatofilozis tedavisi için oksitetrasiklin ve tilosin kombinasyonu önerildi ve lezyonlar 5. günden itibaren gerilemeye başlayarak zamanla tamamen kayboldu. Sonuç olarak, Saanen oğlaklarında D. congolensis enfeksiyonunun Türkiye'de ilk kez gözlendiği, oksitetrasiklin ve tilosin kombinasyonu ile başarılı bir şekilde tedavi edilebileceği kanısına varılmıştır.

Anahtar sözcükler: Dermatophilus congolensis, oğlak, oksitetrasiklin, tilosin

\section{Introduction}

Dermatophilosis is a dermatitis with acute, subacute and chronic course which is usually exudative and rarely proliferative and observed in animals such as cattle, sheep, goats and horses and sometimes in humans $(8,14)$. The disease is more prevalent especially in humid climates and in regions where ticks of the genus Amblyomma are endemic $(2,6)$. This infection, which is observed in different regions of the world, and also has been reported in sheep and goats in Turkey $(5,12)$. The agent is Dermatophilus congolensis, that is a Gram-positive bacteria with capnophilic, aerobic or facultative anaerobic. This agent has a filamentous structure $(1-5 \mu \mathrm{m})$ consisting of coccoid zoospores $(0.5-1.5 \mu \mathrm{m})(2,5,9)$. The bacterium shows activity in the epidermis layer without affecting the stratum corneum, which is the top layer of the epidermis. The infection can be transmitted through contact with infected animals, passive vectors (ectoparasites) and also through intradermal inoculation by contaminated thorny plants (1). The clinical appearance and the affected body parts vary by the host's individual sensitivity, nutritional and immunological status, heavy rainfall and mechanical trauma. Sporadic dermatophilosis outbreaks can be observed in rainy 
periods when wool or hair remains wet for a long time (1, 6-8, 11).

Lesions are generally observed in the ear, nose, tail, and legs of sheep and goats and also in the back, head, neck and on the sides of the body in cattle. While vesicle, papule, edema or bonding of hair that occur in the early stages of infection are disregarded, the exudate that dries in later periods causes the formation of yellow-brown crusts firmly adhered to the skin (8). These crusts are granular and can often be removed by leaving the bleeding surface $(7,14)$. During healing phase, it is observed that the crusts are removed, new hairs come out or the lesional areas in the patient take a hairless appearance. Itching is not usually observed (8). In goats, lesions first spread over the lips and mouth and then to the feet and scrotum possibly by biting. Lesions may extend to all parts of the body, especially to the dorsal midline and inner parts of the thighs. In some cases, lesions begin in the external ear and may occlude the external auditory canal and the outward-facing part of the external nostrils due to severe crust formation (3). Antimicrobial therapy is used in the treatment of the disease. Long-acting oxytetracycline administration has been reported to be effective in cattle and sheep (7). Furthermore, it is stated that penicillin and streptomycin combination, erythromycin, lincomycin and spectinomycin combination can also be used in sheep (3). In a study (15), it was reported that topical povidone iodine combined with parenteral penicillin administration was successful in the treatment of severe cases. Similarly, Sekin et al. (12) reported that penicillin and streptomycin combinations in goats are effective in the treatment of dermatophilosis. However, Göçmen and Şen (5) reported that the application of injectable penicillin and streptomycin combination in goats with dermatophilosis did not cause a change in the course of the disease. Economic losses due to the disease are related to skin damage in cattle and wool yield in sheep (7). On the other hand, the infection may lead to significant economic losses due to a decrease in meat and milk yields and increases in treatment costs, death and mandatory slaughtering rates (16).

The aim of this study was to determine the treatment efficiency of oxytetracycline and tylosin combination in Saanen goat kids diagnosed with dermatophilosis.

\section{Material and Methods}

Sampling: This study was carried out on 27 Saanen goat kids in the 4-5 month age on a special goat farm in Bigadiç district of Balıkesir Province. It was reported that the lesions observed in goat kids began to form 10 days ago and were transmitted to 27 of 29 goat kids (93.1\%) on the same farm. According to the owners' statement, goat kids were treated against scabies lesions however, no improvement was observed in those animals. The samples were collected from skin lesions (swab, skin and hair samples from lesion areas), performed bacteriological, mycological and ectoparasitological (scabies etc.) analyses.

Direct bacterioscopy: The samples prepared from skin scrapings were detected by the chemical method (methanol), stained with Diff-Quick and examined under an immersion microscope. In addition, in terms of mycotic agents, the samples collected from the superficial and deep areas of the lesional skin regions were treated with $10 \%$ $\mathrm{NaOH}$ and then examined under a microscope with a magnification of 40x.

Bacteriological analysis: The swab and skin scrapings were inoculated into defibrinated sheep blood $\operatorname{agar}(7 \%)$ (1.10886, Merck, Darmstadt, Germany) in two series. One of the series in an anaerobic medium and the other one in the medium with $5-10 \% \mathrm{CO}_{2}$ were incubated at $37^{\circ} \mathrm{C}$ for 5 days. The growing agents were identified according to conventional methods $(5,9)$. Catalase, lactose, dextrose, mannitol, maltose, sucrose and urease tests were used for the identification of $D$. congolensis.

Mycological analysis: The samples of skin scrapings and hair were parallelly inoculated into sabouraud dextrose agar (SDA) (1.05438, Merck) and one of the series was incubated at $25^{\circ} \mathrm{C}$ and the other one was incubated at $37^{\circ} \mathrm{C}$ for 5 weeks.

Ectoparasitic analysis: For this purpose, primarily the hair and skin of the animals were examined macroscopically for ectoparasites. In addition, in terms of mange mites in goat kids, the samples collected from the superficial and deep areas of the lesional skin regions were treated with $10 \% \mathrm{NaOH}$ and then examined under a stereo-microscope.

Treatment: For treatment in goat kids, oxytetracycline (Primamycin LA ${ }^{\circledR}$, Zoetis, USA) at a dose of $20 \mathrm{mg} / \mathrm{kg}$ was administered intramuscularly as a single dose and tylosin (Taylomisin ${ }^{\circledR}$ IE Ulugay, Turkey) at a dose of $15 \mathrm{mg} / \mathrm{kg}$ was administered intramuscularly for 3 days. Furthermore, a $10 \mathrm{mg} / \mathrm{kg}$ dose of cypermethrin pour-on (Cyperon ${ }^{\circledR} \quad 5 \%$, Hektaş, Turkey) was administered for treatment since flea infestation was observed in goat kids.

\section{Results}

Clinical findings: When the intensity of skin lesions was examined, it was observed that localizations were mainly around the head region and some of them were seen at the neck, back, and abdominal region. Appetite and physical examination findings of goat kids were found to be normal.

Direct bacterioscopy: Long filaments consisting of coccoid structures and similar to the tramline were observed in direct bacterioscopy (Figure 1). 


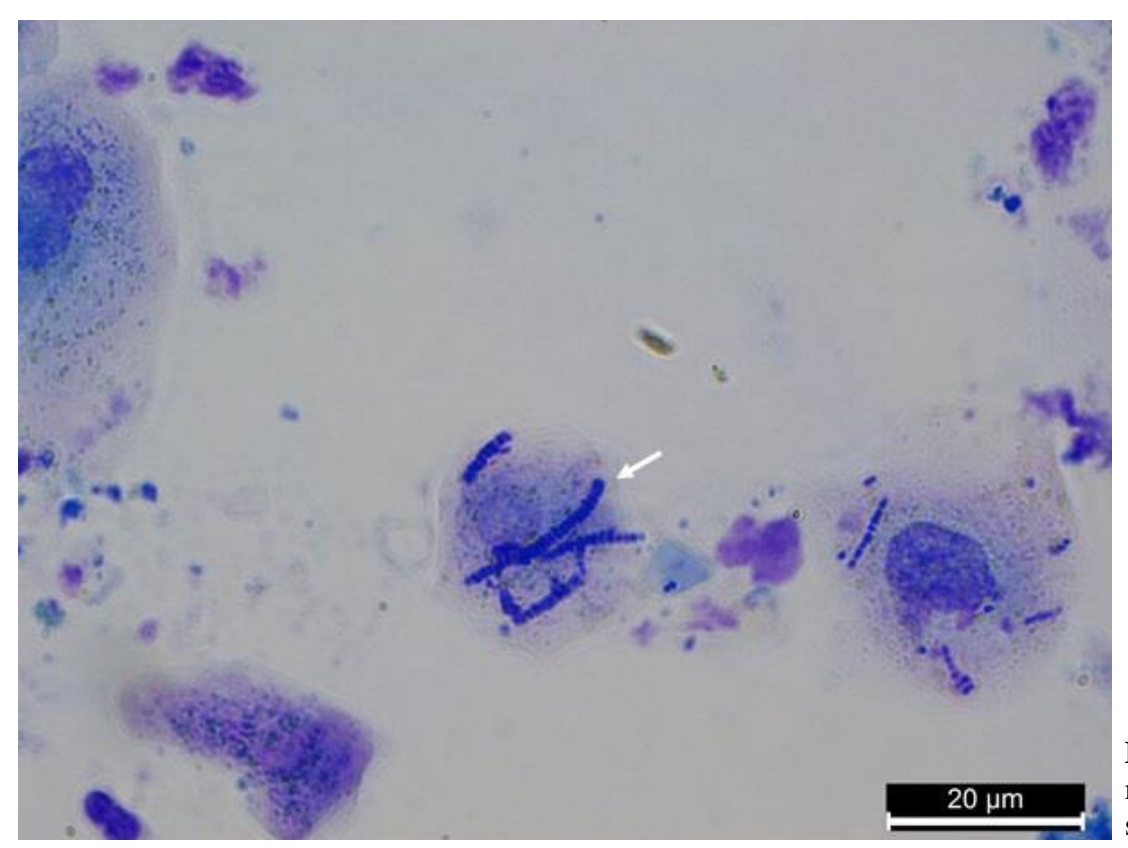

Figure 1. Long filaments (arrow) with multiple rows of cocci seen in scab materials stained with Diff-Quick.

Bacteriological analysis: R-type colonies were observed with 1-2 mm diameter at approximately 72 hours during bacteriological analysis. The identification of $D$. congolensis was performed according to various biochemical tests along with macroscopic and microscopic morphology. Catalase, urease and dextrose tests were determined as positive, but lactose, mannitol, maltose and sucrose tests were negative.

Mycological analysis: No growth was detected in SDA.

Ectoparasitic analysis: In the macroscopic examination, only flea infestation was determined. However, no species identification was done. In addition, scabies infestation was not encountered.

Treatment: The lesions began to heal in 5 days after treatment and completely disappeared over time in all goats.

\section{Discussion and Conclusion}

D. congolensis causes a disease process which mainly presents with skin lesions in various animal species all over the world. The infection is usually observed more intensively in tropical regions. This disease, which has been previously called mycotic dermatitis, is commonly called cutaneous streptothricosis in cattle, goats, and horses, and in sheep, it is also called lumpy wool disease when the wooled areas of the body are affected. Along with the formation of crust, exudative dermatitis, alopecia with the progression of infection are observed during the course of the disease. When the crusts are removed, sometimes there is a bleeding appearance on the skin. Furthermore, it can also be observed that new hair begins to emerge from under the crust $(5,7)$. In goats, it is reported that lesions are mostly localized in the head region and that lesions on the lips and mouth may spread to the feet and scrotum by biting. Moreover, lesions can be observed in the whole body, and also they may occur especially between the back and hind legs. It has been reported that severe crust formation around the ear and nose may sometimes occlude the ear canal and nostrils (3). The lesions have been reported to be limited to the head region in sheep and goats with $D$. congolensis infection (5). In this study, typical crust formations and lesions in goat kids were mostly localized in the head region and were commonly observed over the nose and in the external ear (Figure 2). However, a small number of lesions were also found in the back, abdomen, and legs of some goat kids in the study. Alopecic areas and new hair were detected when the crusts were removed.

Skin damage (ectoparasites, physical wear due to contaminated thorny bushes), excessive moisture, and disease and stress factors causing immunosuppression can be considered among the predisposing factors for clinical disease. It is reported that the loss of the layer of fat on the skin may contribute to the development of the disease. Extremely rainy weather conditions increase the likelihood of clinical disease by causing thinning of the layer of fat on the skin $(6,8,11)$. The fact that the goat kids examined in this study were housed in the same place and intense flea infestation was observed in animals suggests that the flea factor may be effective in transmission. More studies are needed to be able to make a more reliable interpretation in this regard. On the other hand, the facts that the infection was observed in June and that Balıkesir region was partly rainy and had high moisture content during the relevant period support the information that climate conditions are effective in the epidemiology of the infection $(7,9)$. 


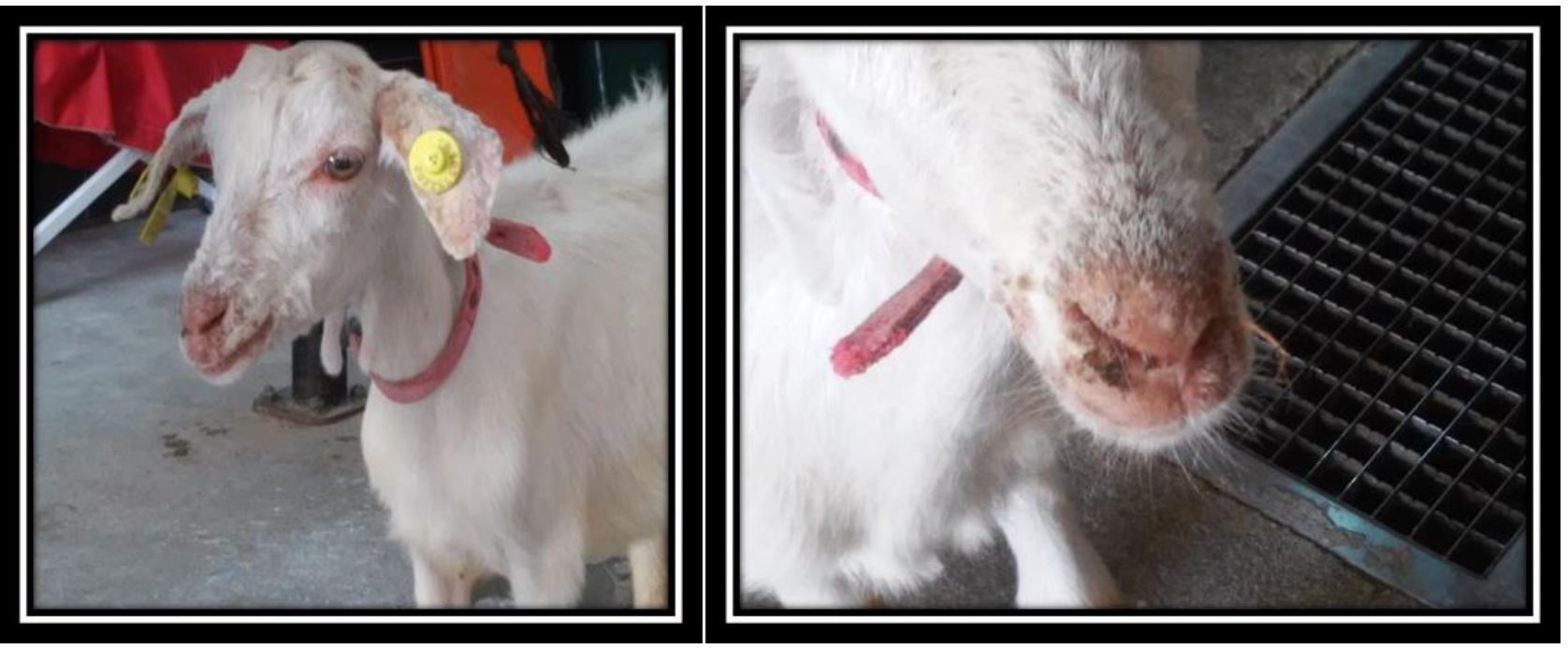

Figure 2. Lesions around the mouth and nose in goat kids with dermatophilosis.

There is no specific treatment for D. congolensis infection (2). It is stated that clinical symptoms may improve spontaneously in animals with a small number of agent input and developed immune system (7). However, the infection may cause significant economic losses since it is associated with high morbidity and mortality. Briefly, the agent leads to significant economic losses by causing decreases in milk and meat yield in various animal species. In this study, it was observed that there was no significant loss of weight in goat kids. This can be explained by the early diagnosis and treatment of the infection due to the high sensitivity of the local people on animal health.

In the studies carried out, $D$. congolensis has been reported to be susceptible to various antibiotics. These antibiotics include erythromycin, spiramycin, penicillin G, ampicillin, chloramphenicol, streptomycin, amoxicillin, tetracycline and novobiocin $(7,10,13)$. Longacting oxytetracycline administration in cattle and sheep has been reported to be effective in treatment (7). Furthermore, it is stated that penicillin and streptomycin combination, erythromycin, lincomycin and spectinomycin combination can also be used in sheep (3). Sekin et al. (12) reported that penicillin-streptomycin combinations have been to be effective in treatment in sheep and goats with $D$. congolensis infection. Göçmen and Şen (5) reported that there was no change in the course of the disease despite the administration of injectable penicillin-streptomycin combination for 5-6 days in animals with lesions among sheep and goats with dermatophilosis. They considered that the failure of penicillin-streptomycin administration was due to the fact that the treatment was performed in the advanced stages of the disease (5). Although there are studies on the use of long-acting tetracyclines and macrolides in sheep and cattle, studies in goats are scarce (or limitied). For this reason oxytetracycline and tylosin combination was used to test the efficacy and success of these drugs in the study. In this study, it was determined that the lesions regressed from day 5 and disappeared completely (Figure 3) over time along with the parenteral tylosin administration for 3 days with parenteral single dose long-acting oxytetracycline in goat kids. After the study, the herd was followed for 4 months and it was observed that no recurrence or a new case was detected.

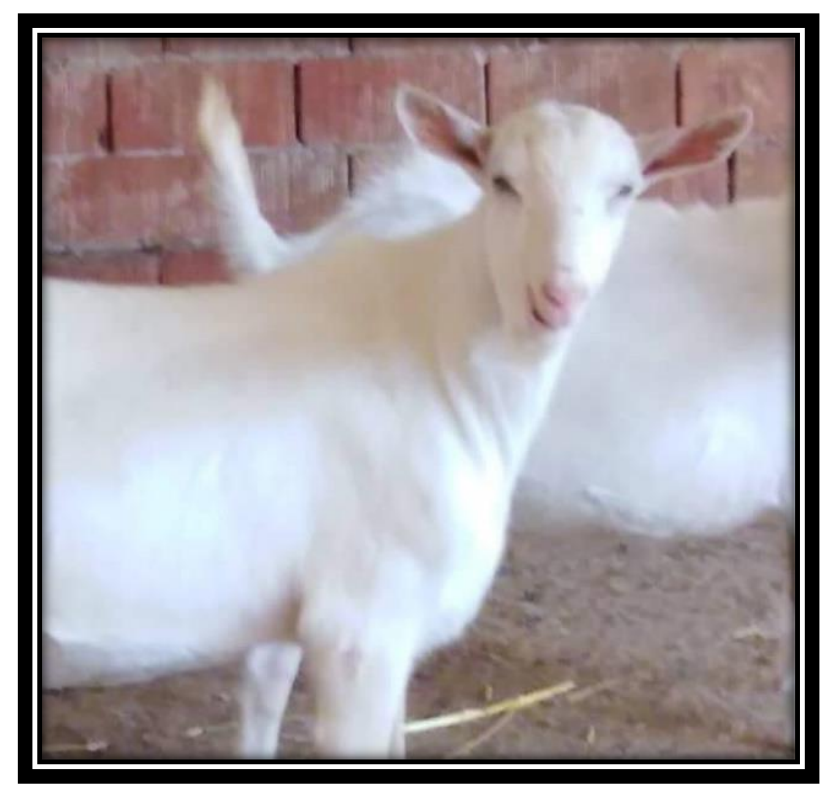

Figure 3. The goat kid after treatment.

In conclusion, a few studies related the in vitro antibiotic susceptibility have been performed against $D$. congolensis (4). However, there are limited information in animals (in vivo). D. congolensis infection which was treated with oxytetracycline and tylosin combination successfully, was reported in Saanen goats for the first time in Turkey. 


\section{Financial Support}

This research received no grant from any funding agency/sector.

\section{Ethical Statement}

This study does not present any ethical concerns.

\section{Conflict of interest}

The authors declared that there is no conflict of interest.

\section{References}

1. Ambrose N, Lloyd D, Maillard JC (1999): Immune responses to Dermatophilus congolensis infection. Parasitol Today, 15, 295-300.

2. Chitra MA, Jayalakshmi K, Ponnusamy P, et al (2017): Dermatophilus congolensis infection in sheep and goats in Delta region of Tamil Nadu. Vet World, 10, 1314-1318.

3. Constable PD, Kenneth W, Hinchcliff KW, et al (2017): Veterinary Medicine. A textbook of the diseases of cattle, horses, sheep, pigs and goats. WB Saunders Ltd, Missouri.

4. Domingues PF, Guerra ST, de Paula CL, et al (2017): Successful therapy in unusual generalized Dermatophilus congolensis infection in a calf based on modified in vitro disk diffusion test. Arq Inst Biol, 84, 1-7 (e0382017).

5. Göçmen H, Şen A (2013): Bir koyun-keçi sürüsünde gözlenen Dermatophilus congolensis infeksiyonu. Uludag Univ J Fac Vet Med, 32, 63-66.

6. Loria GR, La Barbera E, Monteverde V, et al (2005): Dermatophilosis in goats in Sicily. Vet Rec, 156, 120-121.
7. Moriello KA (2019): Overview of dermatophilosis. Available at https://www.msdvetmanual.com/ integumentary-system/dermatophilosis/overview-ofdermatophilosis (Accessed May 30, 2019).

8. Or ME, Bakırel U (2006): Skin diseases. 431-470. In: Y Gül (Ed), Geviş Getiren Hayvanların İç Hastalıkları. Medipress, Malatya.

9. Quinn PJ, Markey BK, Leonard FC, et al (2011): Veterinary Microbiology and Microbial Disease. WileyBlackwell, West Sussex.

10. Ranjithkumar M, Saravanan M, Krishnakumar S, et al (2018): Dermatophilosis in a buffalo: A case report. Buffalo Bull, 37, 253-258.

11. Roberson JR, Baird AN, Pugh DG (2012): Diseases of the Integumentary System. 256-290. In: DG Pugh, AN Baird (Eds), Sheep and Goat Medicine. WB Saunders, Missouri.

12. Sekin S, Elitok ÖM, Elitok B, et al (2002): Natural ovine dermatophilosis: Clinical aspects and efficacy of penicillin/streptomycin treatment. Turk J Vet Anim Sci, 26, 1013-1019.

13. Tresamol PV, Saseendranath MR (2013): Antibiogram of Dermatophilus congolensis isolates from cattle. Int J Live Res 3, 117-121.

14. Van Tonder EM, Horner RF (1994): Dermatophilosis. 1472-1481. In: JAW Coetzer, GR Thomson, RC Tustin (Eds), Infectious Diseases of Livestock with Special Reference to Southern Africa. Oxford University Press, New York.

15. Yeruham I, Elad D, Perl S (2003): Dermatophilosis in goats in the Judean foothills. Revue Méd. Vét., 154, 785788.

16. Zaria LT (1993): Dermatophilus congolensis infection (dermatophilosis) in animals and man! An update. Comp Immunol Microbiol Infect Dis, 16, 179-222. 